\title{
Research on Applying Three-dimensional Teaching Material in Vocational Education
}

\section{Wang Wei}

School of Information Science and Technology of the Northeast Normal University, The ministry of education of digital learning support technology engineering research center

Changchun, China

\section{Xu Xin}

School of Information Science and Technology of the Northeast Normal University

Changchun, China

\begin{abstract}
Vocational colleges is the important base of cultivating applied talents in our country, vocational education pay more attention to cultivate the students' speaking ability. To emphasize the ability training, teaching reform, teaching mode innovation in vocational colleges teaching, we based on the theoretical exploration and practical observation research basing on connotation and value of the three-dimensional teaching material to analysis, and putting forward a method of applying three-dimensional teaching material in vocational education.
\end{abstract}

Keywords-Vocational education; Three-dimensional teaching material; Application methods

\section{INTRODUCTION}

In today's world, vocational education has become a common action to cope with the crisis, to promote employment and to meet the challenge of new industrial revolution [1]. Vocational education is an important part of the national education system and the human resource development, and the important way for the young man to open the gates of becoming a useful person, Shouldering the important responsibility of cultivating talents, the inheritance of technical skills, and promoting employment entrepreneurship. Therefore, it is necessary to pay high attention to vocational education and to speed up the development of it.

Vocational education with cross profession and education, work and study in the field of vision, enterprise and school's boundaries, etc[2]. It makes the current vocational education do not adapt obviously to the educational philosophy. In the aspect of education teaching, it pays more attention to the classroom teaching, rather than cultivating practice ability. The teaching and practice are disjointed. And students can't operate proficiently with the skills studied in class. In terms of content construction, that is old and outdated technology.

China attaches great importance to the education informatization, and the information technology will promote teaching reform as a national strategy. Therefore, the key of promoting vocational education teaching reform is how to use

\author{
Wang Xiaohan \\ School of Information Science and Technology of the \\ Northeast Normal University \\ Changchun, China \\ Feng Cong \\ School of Information Science and Technology of the \\ Northeast Normal University, \\ Changchun, China
}

information technology in new era of the vocational education [3], the application of new technology and new ideas to promote the effective development of teaching and the threedimensional teaching materials arises at the historic moment.

\section{THE CONNOTATION AND STRUCTURE ANALYSIS OF THREE- DIMENSIONAL TEACHING MATERIALS}

The three-dimensional teaching materials consist of paper textbooks utilize and blend into digitized resources, environment and service developed by Augmented Reality, Virtual Simulation Technology, Learning Analytics, Intelligent Diagnosis Technology and so on [4-5]. The threedimensional teaching materials take paper textbooks as main part, including four important components-course learning resources, self-learning environment, interactive classroom environment, and study analysis service. as is shown in figure 1 and figure 2 .

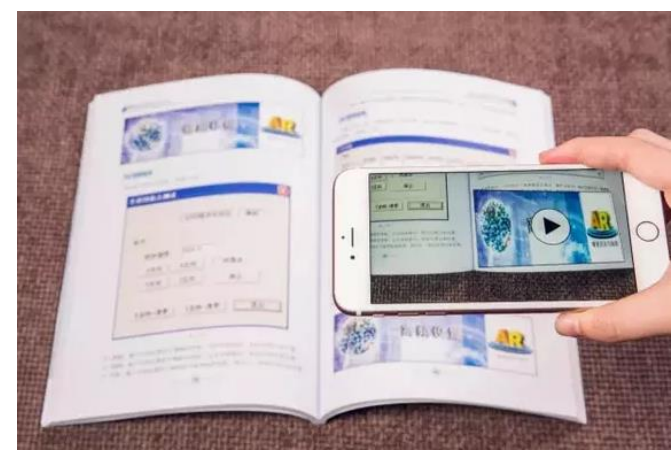

Fig. 1. Three-dimensional teaching material application 


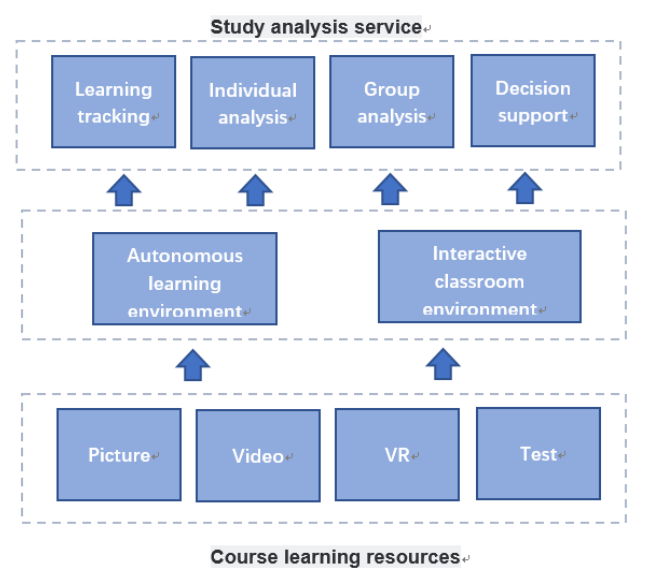

Fig. 2. Three-dimensional teaching material structure char

- Paper textbook: It is the core of the course teaching materials. Compared with the traditional paper textbooks, paper textbooks included by threedimensional teaching materials can be scanned and identified digitally. That can link up with course learning resources, self-learning environment, and study analysis service flexibly.

- Course learning resources: There are course learning resources corresponding for every identifier can be scanned in the paper textbooks. The types of them include pictures, videos, interactive virtual simulation tools, testing practice and so on. The pictures and video mainly return the contents of the textbooks, and make them to be visualization and materialization. According to business process needs, Interactive virtual simulation tools can simulate the working environment and machines to support students operation, completing the transformation from application knowledge to ability. And students can know their mastery by testing practice, consolidate and strengthen what they learn pointedly.

- Self-learning environment: Depend on that handheld mobile terminal provide support for student learning, students use app scan paper textbooks, students enter into the personal learning environment, study corresponding course learning resources [6], including safety education, the use of devices, watching cases, situational experience, the operation of business process, knowledge and skills test and so on. what's more, it will record the students' whole learning situation.

- Interactive classroom environment: From the point of supporting teachers' teaching and students' study, it can provide strong support for the classroom teaching activities. Teachers can monitor the students program, control the class schedule and discipline, push and share the resources or the student individual learning outcomes. Students can result feedback to the teacher in a timely manner in the learning process, and get specific feedback and suggestions. Meanwhile, they can form study groups, research and inquiry learning tasks together.

- Study analysis service: Based on detailed analysis of active record and data of students on learning content, learning process, learning time and learning resources application in the self-learning environment, It can dig the student individual characteristics and learning styles, recommend more suitable learning solutions for students, and provide the basis for teachers' personalized guidance. Besides that, it can excavate students group characteristics and the knowledge skills, and provide decision support for the teaching process optimization and the appropriate intervention.

\section{THREE-DIMENSIONAL TEACHING MATERIAL VALUE AND} SIGNIFICANCE

Resource has important value for education, and the resource types about educational materials are relatively abundant. The main research associated with threedimensional teaching materials the traditional textbooks, three-dimensional teaching material, electronic textbooks, etc. Now we will contrastive analysis detail by detail [7].

\section{A. The three-dimensional teaching material can enhance the interest of traditional textbooks}

Compared with the narrow textbooks, most traditional textbooks printed in black and white paper, by mixing typesetting. Their content often organized from the unit, module, chapters and exercises. In the process of information technology to promote teaching reform, the effects around the presentation and demonstration of teaching contents, the access to information and learning of students are remarkable. But the reform of the teaching material itself is negligible.

Three-dimensional teaching material real opens the windows of the studying from traditional paper study to the digital learning by scan identifying. At the same time, the three-dimensional teaching materials tend to color printing, and inclined to the organization of the contents from the Angle of students learning experience. In addition, the traditional textbooks only achieve one-way communication without answer of students and teaching materials, but the threedimensional teaching material can provide two-way deep interaction for students and resources on a handheld mobile device.

\section{B. The three-dimensional teaching materials can blend the traditional three-dimensional teaching material's construction and application}

Compared with general teaching materials, at present the definition of three-dimensional teaching material commonly: "... on the basis of the traditional paper textbooks, centering on the discipline curriculum, by providing a variety of teaching resources, is a whole teaching and learning solutions ". Threedimensional mainly reflects in the richness and diversity of resource construction, such as $\mathrm{CD}$, network curriculum, the traditional textbooks, etc. There are even some researches regard some services such as community and consultation as construction content. 
But on the whole, compared with the traditional paper textbooks, The three-dimensional teaching materials with diversified resources have characteristics on many concentric rings, each cross, manual cohesion. Therefore, teachers need to organize and guide students to make use of the threedimensional teaching materials. Thus we can conclude that there is obviously disconnect phenomenon in teaching content and process, teaching methods and means. While the threedimensional teaching materials achieve the seamless transition of textbooks and digital resources, the seamless transformation of learning and teaching activities, and the seamless combination of teaching content and teaching organization through the activated and enhance paper textbooks, using mobile terminals scan.

\section{The Three-dimensional teaching material can achieve a transition from electronic texts to traditional materials smoothly}

Electronic textbooks realize the digital of knowledge and mediumize of presentation. When students use electronic textbooks, they need experience accumulation of digital reading, the adaptation to the digital approach to learning, the support of digital reading devices, and the using of digital resources within reach. However, the soil of electronic textbooks application is not fertile, and its application range is not wide.

Technology is to serve the teaching, rather than serving technology teaching. If electronic textbooks just digitize content and teachers use electronic textbooks just medium the contents of the paper, efficiency of electronic textbooks can't get good play. On the other hand, even with electronic textbooks, traditional textbooks are also essential in basic education and some vocational colleges, colleges and universities. How the electronic textbooks and traditional textbooks can be complement each other need to give full play to the teacher's teaching design art.

\section{THE THREE-DIMENSIONAL TEACHING MATERIAL IN VOCATIONAL EDUCATION APPLICATION METHOD}

\section{A. Make the theoretical knowledge present specifically and Specific and visually}

Due to the interpretation of theoretical knowledge is the indispensable link, therefore in order to better give play to the role of the guidance of the theory knowledge to practice, first of all, we must be prepared to imparting theoretical knowledge. And through the theoretical explanation can make students more systematic study and master the concept of related disciplines, cultivate students' logical thinking ability, which will help to promote students' development of thinking and self-study ability to ascend.

When teaching in theory, teachers can put the threedimensional teaching materials, electronic whiteboards, and other information technology into the teaching activities. And teachers can take advantage of new technology, comprehensive presentation, virtual demonstration, such as strategy, makes theoretical knowledge is relatively more attractive to the interpretation of the traditional boring students, stimulate students' interest in learning more easily. Studies have shown that normal people's attention can last five to eight minutes, so when the classroom teaching activities into more information technology at the same time, can make students more interested in mutual transformation between attention and has no intention of attention, on more operation link potential to accept some theoretical knowledge. It is convenient for teachers' teaching activities to carry out and improve the efficiency of students' learning and mastering of theoretical knowledge.

\section{B. Build a complete and system of practice teaching of technical norms and standards of behaviour}

The students' practical operation in the process of practice teaching is one of the most important teaching activities, involving various technical essentials in the process of practice and action, the act of the technical essentials and prior to the implementation of the training stage, teachers should give students some guidelines and formulate corresponding behavior standard, so that the students under the norms of behavior standard Not only exercise students' practical ability, but also improve the students' conscientiousness, to adapt to the social demand for high-quality technical personnel, to let the students form good habits from the start, to avoid in the process of learning operation and work in the future have a significant error. Three-dimensional teaching material provided by the mistakes and correct demonstration, providing students with a comprehensive range of technical guidance, to avoid major mistakes and cause safety accidents.

In terms of teaching mold and informatization means, we also need to develop more systematic criteria. Teaching tools, molds, information means that the specification is an important platform for the reform of practice teaching method, so the application of three-dimensional teaching information means at the same time, pay attention to the standardization of its use, avoid the improper operation lead to its impact on teaching.

\section{Figures and Tables Creating real learning situations, and to promote students' active learning}

Situational teaching is a teacher in the teaching process for the introduction of the corresponding knowledge targeted or create more vivid and concrete, conform to the teaching contents and to complete the teaching goal plays a role in promoting the situational teaching method. Simulation situation causes the student to obtain more learning experience. Students in the appropriate context, not only can be more effective understanding of the teaching material the theory knowledge, also can improve students' learning interest and logical thinking ability.

Teachers in the process of using three-dimensional teaching materials for practice teaching can take advantage of its technical characteristics, by combining practical classroom equipment support, so as to create more vivid and concrete situation. Assisting with images of three-dimensional teaching materials for creating situation not only provide convenient for the explanations of the teachers, but also facilitate the students to understand and study. In practice teaching, the way of students enhance the understanding of the production process and understand is mainly achieved by means of autonomous learning and training. Based on the situation of the process of teaching can make boring theory into actual operation process. 
And at this time, the three-dimensional teaching materials of the VR and AR technology can be used more and more, so as to represent the virtual situation of the related theory for students, which makes the students master relevant theoretical knowledge with watching the reappearance of the virtual scene at the same time, and combine to the actual operation training. The purpose of this practice is that to improve the standard operation consciousness, at the same time more quickly and accurately grasp the subject knowledge [8].

\section{Promote the teaching evaluation reform and accurate student}

Outside the classroom, students can learn according to their own situation to set the content or discovery learning, thus effectively complement, ramming or extended learning content [9]. In the process of knowledge acquisition, students' learning can vary from person to person with differentiated learning, and through abundant resources form consolidate knowledge without mastering; with the process of forming ability, students can be targeted according to the individual differences of special promotion in augmented reality work environment.

According to students' autonomous learning environment in the learning content, learning process, learning time and learning resources application detailed activity record and data analysis, Three-dimensional teaching material to dig up the student individual characteristics and learning style, and recommend more suitable for students learning solutions, provide the basis for personalized guidance teachers; And mining characteristic and the knowledge, skills, student groups, and appropriate intervention to provide decision support for the teaching process optimization.

\section{CONCLUSION}

The deep integration of Information technology and subject teaching aims to enhance students' learning in the depth of the fusion, promote students' deep learning, cultivate the students' advanced thinking and ability. Three-dimensional teaching material will be printed materials as the core, and greatly enriched the traditional textbooks in subject learning resources environment and the learning, autonomous learning environment, classroom interaction analysis service, etc. Finally, it provides a breakthrough for vocational education classroom teaching change, and thereby to realize the change of teachers' roles and students.

Teacher, who role changes from the star of the classroom to the director of learning, organizes curriculum content by the real business process, and then design scientific and reasonable teaching activities which serves students employment as the guidance. It arouses and maintains students' learning motivation, accurately understand the students and to provide personalized guidance. Students, whose role change from the audience to the leader in the classroom, by the embedded scene simulation, follow their own learning through experience, inquiry and cooperation process is complete meaning construction and skills training. Media, whose role changes from the teacher's teaching tools into student learning partners, is widely used in the safety education, the memorization of equipment, the real operation process, the results express, and the sharing. The threedimensional teaching material's application range is not wide, and the application of the relatively is in a short time. Therefore, the three-dimensional teaching material in the subject application case design and implementation, model combing with the application of the method is applied to the summary of the research results of need further exploration and induction.

\section{ACKNOWLEDGMENT}

Thanks for the ideal factory providing THE threedimensional teaching material and practice demonstration base.

\section{REFERENCES}

[1] Zhangyu, XiaoFengXiang. Vocational education: promoting the modernization of agriculture engine $[\mathrm{J}]$. Journal of vocational and technical education, 2012, (34): 66-70.

[2] HangRuiYou zhu-xing ge, Zhu Jizhi. Higher vocational education of university-enterprise cooperation value identity thinking $[\mathrm{J}]$. Journal of education and profession, 2012, (12): 18 to 20

[3] YuShui. How to promote information technology education change [N]. China education news, 003 (003).

[4] Huang Ronghuai, Guo Fang. Design and development of threedimensional teaching materials $[\mathrm{J}]$. Journal of modern education technology, 2008, (10): 105-109.

[5] Distance education under the condition of autonomous learning subjectification electronic teaching material design, the method based on mind mapping.http://www.360doc.com/content/15/1114/17/7152790_5.

[6] Duan Boyuan. Media convergence under the transformation and upgrading of the university teaching material $[\mathrm{J}]$. Journal of modern press, 2015. (01): 33-36

[7] Chu Tianbin, Li Shaoming. Under the background of mobile Interne the applications study of three-dimensional teaching materials published [J]. Journal of published research, 2015, (02): 39-42.

[8] Wang wei, Zhong Shaochun ShangJianXin. Secondary vocational system scheme of digital resources construction and promote the strategy research [J]. China audio-visual education, 2014, (5): 113-120.

[9] Li Hongyan, Lin Shiyuan. Based on the theory of independent study, network education to make an appointment type teaching mode study [J] Journal of education, 2013, (4): 93-96 